\title{
DynamicSainT
}

Jilid. V No. 1., April 2020

\section{FAKTOR-FAKTOR PENGHAMBAT MENARA ALFA OMEGA DI KOTA TOMOHON}

\author{
Jendry Masinambow, ST., MT \\ Jurusan Teknik Sipil, Universitas Kristen Indonesia Tomohon \\ chrisvia_m@yahoo.com
}

\begin{abstract}
ABSTRAK
Pada pekerjaan proyek konstruksi biasanya terjadi kendala pada pekerjaan proyek tersebut, baik kendala yang memang sudah diperhitungkan maupun kendala yang di luar perhitungan perencana. Metode Rangking digunakan untuk menentukan Rangking para responden dan memberikan perioritas terhadap variable studi, setelah pengumpulan data dari responden, kemudian di analisis dengan nilai Mean, yang merupakan teknik penjelasan kelompok yang didasarkan dari nilai rata-rata tersebut untuk mendapatkan nilai Mean pengolahan data kuisioner menggunakan program SPSS dengan metode analisis Descriptives. Dari hasil penelitian didapatkan urutan rangking-rangking tiap faktor yang menjadi penyebab keterlambatan penyelesaian proyek. Faktor-faktor yang menjadi penyebab utama yang mempengaruhi keterlambatan penyelesaian proyek pembangunan Menara Alfa Omega yaitu Kekurangan bahan konstruksi, Perubahan material pada bentuk, fungsi, dan spesifikasi, Keterlambatan pengiriman bahan, Kerusakan peralatan, Ketersedian keuangan selama pelaksanaan, Keterlambatan proses pembayaran oleh owner, Masalah pembebasan lahan di lokasi, Kekurangan tenaga kerja, Kemampuan tenaga kerja, Perbedaan jadwal sub kontraktor dalam penyelesaian proyek. Dari faktor-faktor keterlambatan yang telah didapat di sarankan beberapa alternative penyelesaian.
\end{abstract}

Kata Kunci : Faktor-faktor keterlambatan, SPSS for windows

\section{PENDAHULUAN}

\subsection{Latar Belakang}

Sekarang ini pembangunan di berbagai bidang sedang giat dilaksanakan oleh bangsa Indonesia. Pembangunan adalah usaha untuk menciptakan kemakmuran dan kesejahteraan rakyat. Oleh karena itu, hasil pembangunan harus dapat dinikmati oleh seluruh masyarakat sebagai peningkatan kesejahteraan lahir dan batin secara adil dan merata. Sejalan dengan kepesatan pembangunan fisik tersebut, maka mulai berdiri pula perusahaan-perusahaan yang bekerja sebagai pelaksana maupun perencana, baik untuk pembangunan gedung, jalan maupun irigasi. Hal ini dilatarbelakangi harapan untuk mendapatkan keuntungan yang besar.

Keterlambatan proyek konstruksi bisa saja disebabkan salah dalam melakukan estimasi waktu yang dibutuhkan untuk menyelesaikan proyek dalam tahap perencanaan, atau bermacam-macam kemungkinan misalnya disebabkan Manajemen yang tidak tepat, masalah bahan material, tenaga kerja, peralatan, keuangan, dan lingkungan yang tidak mendukung sehingga terhambatnya pelaksanaan proyek. Dan secara pasti mengakibatkan keterlambatan proyek.

Keterlambatan proyek bagi kontraktor akan mengalami kerugian waktu dan biaya, karena keuntungan yang diharapkan oleh Kontraktor akan berkurang, atau bahkan tidak mendapatkan keuntungan yang diharapkan oleh Kontraktor akan berkurang, atau bahkan tidak mendapat keuntungan sama sekali.Bagi Owner, keterlambatan penyelesaian pekerjaan proyek akan menyebabkan kerugian terhadap waktu operasi hasil proyek, 


\section{DynamicSainT}

Jilid. V No. 1., April 2020

sehingga penggunaan hasil pembangunan proyek menjadi mundur atau terlambat.

Dalam pelaksanaan proyek konstruksi tepat waktu, dapat di pastikan menguntungkan kedua belah pihak, oleh sebab itu perusahaan yang baik akan selalu berusaha melaksanakan sesuai waktu yang telah di tetapkan atau berusaha meminimalkan keterlambatan dengan memilih tindakan koreksi yang perlu dilakukan dan mengambil keputusan berdasarkan analisa dari berbagai faktor keterlambatan. Oleh sebab itu diperlukan kajian untuk mengindentifikasi dan menganalisa faktor-faktor yang mempengaruhi keterlambatan proyek. .

\subsection{Perumusan Masalah}

Adapun rumusan masalah dalam penelitian ini adalah :

1. Faktor-faktor yang menyebabkan keterlambatan pekerjaan proyek konstruksi.

2. Alternatif penyelesaian keterlambatan pekerjaan proyek konstruksi.

\subsection{Pembatasan Masalah}

Agar penelitian ini tidak menyimpang dari tujuan awal, maka dilakukan pembatasan penelitian:

- Faktor-faktor yang diteliti adalah yang berkaitan langsung dengan penyebab keterlambatan penyelesaian proyek.

- Pengisian kuisioner hanya dibagikan kepada kontraktor dan konsultan proyek konstruksi.

- Analisis data dengan cara pemprograman komputer SPSS

\subsection{Tujuan Penelitian}

1. Untuk mengidentifikasikan dan menganalisis faktor-faktor penyebab keterlambatan penyelesaian proyek.

2. Untuk mencari urutan ranking dari tiap faktor serta mencari faktor utama yang mempengaruhi keterlambatan penyelesaian proyek.

\subsection{Manfaat Penelitian}

Secara umum manfaat dari penelitian ini adalah untuk mendapatkan hasil penelitian yang diharapkan dapat membatu meminimalisir keterlambatan dan sebagai pedoman dalam peleksanaan proyek yang akan datang

\section{KAJIAN PUSTAKA}

\subsection{Proyek Konstruksi}

Di dalam suatu proyek konstruksi terdapat berbagai kegiatan yang dilakukan oleh orang-orang yang terlibat didalam proyek itu sendiri. Kegiatan proyek dapat diartikan sebagai suatu kegiatan sementara yang berlangsung dalam jangka waktu terbatas, dalam alokasi sumber dana tertentu dan dimaksudkan untuk melaksanakan tugas yang sasarannya telah digariskan dengan tegas. Banyak kegiatan dan pihak-pihak yang terlibat di dalam pelaksanaan proyek konstruksi menimbulkan banyak permasalahan yang bersifat kompleks.

\subsection{Manajemen Konstruksi}

Manajemen adalah proses perencanaan, pengarahan, pengorganisasian, dan pengawasan terhadap usaha-usaha para anggota organisasi dan penggunaan sumber daya organisasi lainnya. Manajemen konstruksi memiliki ruang lingkup yang cukup luas, karena mencakup tahap kegiatan sejak awal pelaksanaan pekerjaan sampai dengan akhir pelaksanaan yang berupa hasil pembangunan. Tahap kegiatan tersebut pada umumnya dibagi menjadi empat tahap yaitu perencanaan (planning), pengorganisasian (organizing), pelaksanaan (Actualing), dan pengawasan (Controlling).

Manajemen konstruksi juga dapat diartikan, sebagai suatu metode system proses atau prosedur dalam pengolahan suatu proyek konstruksi secara terpadu, sistematis, efektif, dan efisien untuk mencapai tujuan pembangunana proyek konstruksi tersebut dimulai dari perencanaan, perancangan, pelelangan, atau pengadaan dan pelaksanaan, sedangkan tujuan utama manajemen 


\section{DynamicSainT}

Jilid. V No. 1., April 2020

konstruksi adalah mengelola proses transformasi gambar-gambar dan spesifikasi menjadi bentuk bangunan fisik sehinga mampu menghasilkan produk dan pelayanan yang merupakan tujuan fungsional proyek.

\subsection{Perencanaan (Planning)}

Perencanaan salah satu fungsi penting dalam manajemen konstruksi, yaitu memilih dan menentukan langkah-langkah kegiatan yang akan datang dan diperlukan untuk mencapai tujuan dan sasaran. Unsur-unsur pelaksanaan erat hubungannya dengan pengolahan suatu proyek adalah jadwal, anggaran, prakiraan, dan sasaran.

\subsection{Pengorganisasian (Organizing)}

Penyusunan organisasi akan melibatkan unsur-unsur pelaksanaan pembangunan sebagai berikut :

1. Pemberi tugas (Owner, Employer, Clien, Bouwheer)

2. Perencana (Desainer)

3. Kontraktor (Contractor)

4. Kontraktor berbentuk Terbatas (PT)

\subsection{Pelaksanaan (Actuating)}

Kegiatan-kegiatan pelaksanaan harus menuju kepada arah tujuan yang hendak dicapai dan tetap dalam arah kebijaksanaan yang telah ditetapkan. Dalam rangka pelaksanaan ini unsur pimpinan dan pengendalian merupakan alat untuk menjamin bahwa pelaksanaan diarahkan kepada tujuannya, yaitu:

1. Pimpinan akan bertanggung jawab terhadap gerak organisasi menuju sasaran yang telah ditetapkan, dimana pimpinan harus mampu mempengaruhi dan menggerakkan orang bawahannya untuk bekerja sama dalam hubungan usaha bersama.

2. Pengendalian merupakan hal yang tidak dapat dipisahkan dari proses kepemimpinan. Pengendalian adalah kegiatan untuk menjamin sesuai tidaknya hasil karya dengan rencana yang telah ditetapkan, termasuk tindakan koreksi terhadap kesalahan dan penyimpanan.

3. Koordinasi adalah suatu proses yang menghubungkan rangkaian, kegiatan yang bertujuan untuk menserasikan setiap langkah dan kegiatan dalam organisasi, agar tercapai gerak yang cepat untuk mencapai sasaran dan tujuan koordinasi yang baik memerlukan saling pengertian antara semua anggota organisasi tentang tugas wewenang cara kerja, serta tangung jawab masing masing dan mempunyai peranan menghubungkan bagian - bagian dengan pimpinan dan pelaksana.

\subsection{Pengawasan (Controlling)}

Pengawasan adalah suatu proses penilaian selama pelaksanaan kegiatan dengan tujuan agar hasil pekerjaan sesuai dengan rencana, dengan mengusahakan agar semua anggota kelompok melaksanakan kegiatan berpedoman pada perencanaan, serta mengadakan tindakan korektif dan perbaikan atau penyesuaian apabila terjadi penyimpangan.

\subsection{Sasaran Proyek Konstruksi}

Sasaran adalah tujuan yang spesifik dimana semua kegiatan diarahkan dan diusahakan untuk mencapainya. Setiap mempunyai tujuan yang berbeda-beda, misalnya pembuatan rumah tinggal, jalan dan jembatan, maupun instalasi pabrik, dapat pula produk hasil kerja penelitian dan pengembangan. Selama proses mencapai tujuan tersebut terdapat tiga sasaran pokok proyek, yaitu besarnya anggaran yang dialokasikan, jadwal kegiatan, dan mutu yang harus dipenuhi.

Ketiga sasaran tersebut erat hubungannya dan bersifat saling terkait. Artinya, jika ingin meningkatkan kinerja, produk yang telah disepakati dalam kontrak, maka umumnya harus diikuti denga 


\section{DynamicSainT}

Jilid. V No. 1., April 2020

menaikkan mutu yang berakibat pada naiknya biaya rencana. Sebaliknya apabila ingin menekan biaya, maka akan menurunkan mutu hasil akhir, dan waktu pelaksanaanya. Dari segi teknis, ukuran keberhasilan proyek dikaitkan dengan sejauh mana ketiga sasaran tersebut terpenuhi.

\subsection{Pengertian Keterlambatan Proyek}

Keterlambatan proyek konstruksi berarti bertambahnya waktu pelaksanaan penyelesaian yang telah direncanakan dan tercantum dalam dokumen kontrak. Penyelesaian pekerjaan tidak tepat waktu adalah merupakan kekurangan dari tingkat produktifitas dan sudah tentu kesemuanya ini akan mengakibatkan pemborosan dalam pembiayaan, baik berupa pembiayaan langsung yang dibelanjakan untuk proyekproyek pemerintah, maupun berwujud pembengkakan investasi dan kerugiankerugian pada proyek-proyek swasta.

Peran aktif manajemen merupakan salah satu kunci utama keberhasilan pengelolahan proyek. Pengkajian jadwal proyek diperlukan untuk menentukan langkah perubahan mendasar agar keterlambatan penyelesaian proyek dapat dihindari atau dikurangi.

\subsection{Dampak Keterlambatan}

Keterlambatan proyek akan menimbulkan kerugian pada pihak kontraktor, konsultan, dan owner, yaitu :

1. Pihak kontraktor

Keterlambatan penyelesaian proyek berakibat naiknya overhead, karena bertambah panjangnya waktu pelaksanaan. Biaya overhead meliputi biaya untuk perusahaan secara keseluruhan, terlepas ada tidaknya kontrak yang sedang ditangani.

2. Pihak Konsultan

Konsultan akan mengalami kerugian waktu, serta akan terlambat dalam mengerjakan proyek lainnya, jika pelaksanaan proyek mengalami keterlambatan penyelesaian

3. Pihak Owner

Keterlambatan proyek pada pihak pemilik owner, berarti kehilangan penghasilan dari bangunan yang seharusnya sudah dapat digunakan atau disewakan. Apabila pemilik adalah pemerintah, untuk fasilitas umum misalnya rumah sakit tentunya keterlambatan akan merugikan pelayanan kesehatan masyarakat, atau merugikan program pelayanan yang telah disusun.

\subsection{Penyebab Keterlambatan}

Keterlambatan proyek disebabkan oleh beberapa faktor yang berasal dari Kontraktor, Owner, dan selain kedua belah pihak.

1. Keterlambatan akibat kesalahan

Kontraktor, antara lain :

a. Terlambatnya memulai pelaksanaan proyek.

b. Pekerja dan Pelaksana kurang berpengalaman.

c. Terlambat mendatangkan peralatan.

d. Mandor yang kurang aktif.

e. Rencana kerja yang kurang baik.

2. Keterlambatan akibat kesalahan Owner

a. Terlambatnya angsuran pembayaran oleh Kontraktor.

b. Terlambatnya penyedian lahan.

c. Mengadakan perubahan pekerjaan yang besar.

d. Pemilik menugaskan Kontraktor lain untuk mengerjakan proyek tersebut.

3. Keterlambatan yang diakibatkan selain kedua belah pihak diatas, antara lain ;

a. Akibat kebakaran yang bukan kesalahan Kontraktor, Konsultan, Owner.

b. Akibat gempa, banjir, ataupun bencana lainnya.

c. Perubahan moneter.

\subsection{Rencana Kuisioner}

Tujuan pokok pembuatan kuisioner adalah untuk: 


\section{DynamicSainT}

Jilid. V No. 1., April 2020

a. Memperoleh informasi yang relevan dengan tujuan penelitian.

b. Memperoleh informasi dengan reabilitas dan validitas yang setinggi mungkin.

Kuisioner dirancang dalam tiga kelompok seperti dijelaskan dibawah ini :

1. Data pribadi, yaitu pertanyaan terhadap responden mengenai kedudukan atau jabatan, lama pengalaman responden bekerja pada bidang konstruksi, serta pendidikan responden.

2. Data proyek, yaitu tentang penanganan proyek mengenai keterlambatan, besar keterlambatan yang terjadi.

3. Faktor keterlambatan, yaitu poin-poin tentang faktor-faktor yang sering kali terjadinya keterlambatan, disini dibedakan menjadi Sembilan jenis, yaitu:

a. Faktor bahan (Material) terdiri dari:

1) Kekurangan bahan konstruksi.

2) Perubahan material pada bentuk, fungsi, dan spesifikasi.

3) Keterlambtan pengiriman bahan.

4) Kerusakan bahan di tempat penyimpanan.

5) Keterlambatan pabrikasi khusus bahan bangunan.

6) Kelangkaan karena kekhususan.

7) Ketidak tepatan waktu pemesanan.

8) Dan lain-lain.

b. Faktor tenaga kerja (Man Power) terdiri dari:

1) Kekurangan tenaga kerja.

2) Kemampuan tenaga kerja.

3) Kesukuan atau nasionalisme atau kultur tenaga kerja.

4) Dan lain-lain.

c. Faktor peralatan (Equipment) terdiri dari:

1) Kerusakan peralatan.

2) Kekurangan peralatan.

3) Kemampuan mandor atau operator yang kurang.

4) Keterlambatan pengiriman peralatan.

5) Produktifitas peralatan.

6) Kesalahan manajemen peralatan.
7) Dan lain-lain.

d. Faktor keuangan (Financing) terdiri dari:

1) Ketersedian keuangan selama pelaksanaan.

2) Keterlambatan proses pembayaran oleh Owner.

3) Tidak adanya uang intensif untuk kontraktor, apabila waktu penyelesaian lebih cepat dari jadwal.

4) Situasi perekonomian nasional.

5) Fluktuasi nilai rupiah terhadap dolar.

6) Dan lain-lain

e. Faktor lingkungan (Environment) terdiri dari:

1) Faktor sosial dan budaya.

2) Pengaruh udara panas pada aktifitas konstruksi.

3) Pengaruh hujan pada aktifitas konstruksi.

4) Pengaruh keamanan lingkungan terhadap pembangunan proyek.

5) Dan lain-lain.

f. Faktor perubahan (Change) terdiri dari:

1) Terjadi perubahan desain oleh Owner.

2) Kesalahan desain yang dibuat oleh perencana.

3) Kesalahan dalam penyelidikan tanah.

4) Kondisi permukaan air bawah tanah di lapangan.

5) Masalah pembebasan lahan di lokasi.

6) Dan lain-lain.

g. Faktor hubungan dengan pemerintah (Geoverment Reletion) terdiri dari :

1) Perolehan ijin dari Pemerintah.

2) Perolehan ijin dari tenaga kerja.

3) Birokrasi yang berbelit-belit dalam operasi proyek.

4) Dan lain-lain.

h. Faktor kontrak (Contractual Relationship) terdiri dari : 


\section{DynamicSainT}

Jilid. V No. 1., April 2020

1) Konflik antara kontraktor dan konsultan.

2) Tidak adanya kerja sama antara kontraktor dengan Owner.

3) Keterlambatan Owner dalam pembuatan keputusan.

4) Negosiasi dan perijinan pada kontrak.

5) Perselisihan pekerjaan antara bagian-bagian yang berbeda dalam proyek.

6) Komunikasi yang kurang antara Owner dengan perencana pada perencanaan.

7) Perbedaan jadwal sub-kontraktor dalam penyelesaian proyek.

8) Organisasi yang jelek pada kontraktor dan konsultan.

9) Kontrol kontraktor utama terhadap sub-kontraktor dalam pelaksanaan pekerjaan.

10) Dan lain-lain

i. Faktor waktu dan kontrol (Schedulling and Controlling thechniques) terdiri dari :

1) Persiapan jadwal kerja dan revisi oleh konsultan ketika konstruksi sedang berjalan.

2) Prosedur pemeriksaan dan pengetesan dalam proyek.

3) Tanda-tanda pengontrolan praktisi pada pekerjaan dalam lokasi proyek.

4) Kekurangan tenaga dan manajemen terlatih untuk mendukung pelaksanaan konstruksi.

5) Masalah yang terjadi selama pelaksanaan.

6) Tidak memenuhi perencanaan awal proyek.

7) Persiapan dan ijin Shop Drawing.

8) Menunggu ijin untuk kontrol material.

9) Dan lain-lain.

\section{METODOLOGI PENELITIAN}

3.1 Lokasi Penelitian

1. Nama Proyek : Pembangunan Menara

Alfa Omega

2. Lokasi Proyek : Kota Tomohon

3. Pelaksana Proyek : PT. Cahaya Abadi Lestari

\subsection{Waktu Penelitian}

Waktu penelitian dilaksanakan mulai dari persiapan, survei lapangan, analisis data sampai penyusunan hasil penelitian.

\subsection{Teknik Pengambilan Data}

Dalam penelitian ini, sampel diperoleh dari perusahaan penyediaan jasa konstruksi yang bekerja dan menyelesaikan proyek konstruksi. Pengumpulan data dilakukan dengan cara pengumpulan data primer, yaitu suatu cara mengumpulkan data yang langsung berhubungan dengan responden, tanpa melalui perantara atau pihak lain, misalnya dari suatu badan statistik atau referensi data lainnya, sedangkan data sekunder adalah data yang diambil dari data yang telah ada atau data yang telah disurvei sebelumnya oleh instansi atau badan usaha lain, mencari bahan pustaka yang berkaitan dengan judul untuk menunjang penulisan.

Kuisioner digunakan sebagai alat pengumpul data. Pengambilan sampel penelitian ini menggunakan system random sampling yaitu setiap individu dalam populasi mempunyai kesempatan yang sama untuk dipilih menjadi anggota sampel. Pada umumnya penelitian atau studi tentang masalah hubungan faktor-faktor keterlambatan pelaksanaan proyek dari persepsi Kontraktor proyek.

Selain itu, data pada penelitian ini merupakan data kuantitatif, yaitu suatu data yang dikumpulkan dan diolah untuk mencari atau mendapatkan berapa besar faktor-faktor yang mempengaruhi keterlambatan pekerjaan dan kerugian yang di derita perusahaan konstruksi dalam pelaksanaan proyek tersebut. 


\section{DynamicSainT}

Jilid. V No. 1., April 2020

\subsection{Metode Pengumpulan Data}

Sebelum menyusun kuisioner peneliti melakukan studi dahulu dengan mempelajari teori-teori sebagai dasar pembahasan dan pemecahan masalah yang berupa buku dan bacaan-bacaan lain yang berkaitan dengan masalah yang diteliti. Daftar pertanyaan atau kuisioner ini telah disusun sedemikian sehingga diharapkan dapat memudahkan responden untuk menjawab pertanyaanpertanyaan yang ada. Daftar pertanyaan atau kuisioner tersebut dibagikan kepada responden untuk diisi dengan jalan mendatangi lokasi proyek tersebut. Karena jawaban masih bersifat kualitatif maka perlu dikuantitatifkan dengan jalan memberi nilai / skor masing-masing variabel, adapun nilai / skor diklasifikasikan sebagai berikut :

a) Untuk jawaban tidak berpengaruh diberi skor 1

b) Untuk jawaban agak berpengaruh diberi skor 2

c) Untuk jawaban berpengaruh diberi skor 3

d) Untuk jawaban sangat berpengaruh diberi skor 4

Kuisioner ini diantar langsung oleh peneliti ke lokasi yang dituju serta memberikan penjelasan mengenai hal - hal yang berkaitan dengan penelitian.

\subsection{Pengisian Kuisioner}

Pengisian kuisioner dibagikan kepada responden dengan cara diantar langsung oleh peneliti, dengan maksud meminta pihak responden mengisi kuisioner tersebut. Apabila pihak responden cukup sibuk, maka peneliti meninggalkan kuisioner tersebut, kemudian meminta agar diisi langsung oleh kontraktor yang langsung bekerja pada proyek yang dikerjakan dan akan diambil setelah selang beberapa hari.

\subsection{Pengolahan Data Penelitian}

Setelah seluruh data yang diperoleh melalui kuisioner terkumpul, kemudian diadakan tahapan berikutnya, yaitu analisis data. Analisis studi ini menggunakan metode kuantitatif, yang dioperasikan dengan menggunakan program SPSS (Statistical Package for the Social Sciences) untuk mencari beberapa besar faktor-faktor yang berpengaruh terhadap keterlambatan pelaksanaan proyek, dan paling menentukan berdasarkan urutan rangking dalam setiap penelitian dari masing-masing perusahaan yang diteliti.

\subsection{Diagram Alir Penelitian}

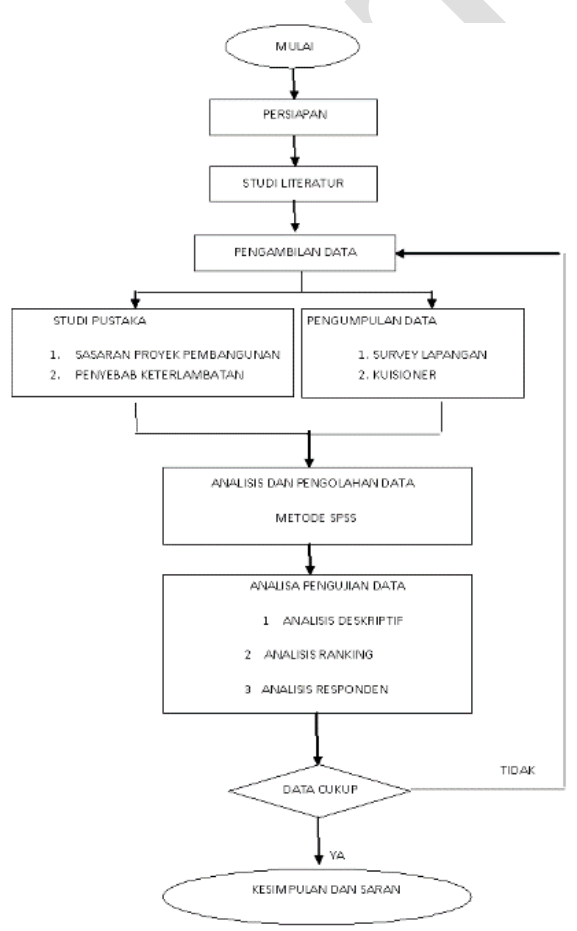

Gambar 1 Bagan Alir Penelitian

\subsection{Metode Analisis}

Setelah semua data terkumpul, kemudian dilakukan analisis data dengan cara kuantitatif, yaitu hasil survey berupa kuisioner dan wawancara dari pakar dan responden diolah sesuai dengan metode yang di gunakan. Adapun metode analisis data yang digunakan pada penelitian ini adalah analisis statik dengan menggunakan IBMSPSS(Statistic Package For Sicial Sciences ) untuk analisa frekuensi dan deskriptive. Metode analisis yang di pakai dalam penelitian ini disesuaikan dengan 


\section{DynamicSainT}

Jilid. V No. 1., April 2020

banyaknya tahap pengumpulan data dengan tahapan sebagai Berikut:

\subsection{Validitas dan Reliabilitas}

Sebelum memulai pengolahan data secara keseluruhan ada baiknya kita menguji terlebih dahulu Reliability $\square$ (keterpercayaan, keterandalan, konsistensi)atau tidaknya suatu data yang di peroleh dengan kuestioner.Ada dua syarat bila suatu instrumen (Kuesioner) dikatakan baik, yaitu Valid dan Reliabel. Suatu instrumen dikatakan valid bila butirbutir pertanyaan atau pernyataan pada instrumen tersebut mampu mengungkapkan sesuatu yang akan diukur oleh instrumen tersebut.

\subsection{Analisis Responden}

Analisis responden dalam penulisan ini adalah analisis mengenai pengolahan data yang digunakan untuk memberi gambaran dari hasil jawaban yang diberikan oleh responden terhadap butir-butir pertanyaan pada kuisioner, dalam bentuk Gambar diagram batang.

\section{HASIL PENELITIAN}

Pengolahan data hasil dari penelitian ini diambil secara keseluruhan dari semua data yang masuk, yaitu sebanyak 25 responden. Tetapi sebelum diambil analisis data secara keseluruhan terlebih dahulu dilihat data berdasarkan item pekerjaan yang mempengaruhi keterlambatan penyelesaian pelaksanaan proyek yang meliputi beberapa faktor, yaitu faktor bahan, tenaga kerja, peralatan, perubahan, hubungan dengan Pemerintah, kontrak, lingkungan, keuangan dan faktor waktu dan kontrol. Sehingga akan terlihat faktor utama yang mempengaruhi keterlambatan penyelesaian pada proyek pembangunan Menara Alfa Omega.

\section{KESIMPULAN DAN SARAN}

\subsection{Kesimpulan}

Dari data penelitian analisis dan pembahasan dapat ditarik kesimpulan, yaitu :

1. Faktor-faktor yang menjadi penyebab utama yang mempengaruhi keterlambatan penyelesaian proyek pembangunan Menara Alfa Omega yaitu:

- Keterlambatan proses pembayaran oleh owner, sebaiknya dari managemen proyek itu harus mengurus proses pembayaran sebelum pencairan.

- Masalah pembebasan lahan di lokasi, sebaiknya revisi kembali perencana dan pelaksanaan proyek tersebut.

- Ketersedian keuangan selama pelaksanaan, maka dari itu untuk mengatasi ketersedian keuangan selama pelaksanaan perusahaan harus ada dana simpanan (modal awal).

\subsection{Saran}

Berdasarkan kesimpulan diatas, maka penyusun mencoba memberikan saran yang mungkin dapat bermanfaat sebagai kemungkinan solusi pencegahan keterlambatan pekerjaan konstruksi :

a) Pihak owner sebaiknya memperhatikan masalah pembebasan lahan dilokasi pembangunan Menara Alfa Omega, untuk itu sebaiknya pihak kontraktor menghubungi owner untuk segara menyelesaikan masalah pembebasan lahan.

\section{DAFTAR PUSTAKA}

1. Duwi Priyanto, 2014. 5 Jam Belajar Olah Data Dengan SPSS 17. Penerbit ANDI.Yogyakarta

2. Jonathan Sarwono, 2014. Riset Skripsi dan Tesis dengan SPSS 22. PT. Elex Media Komputindo. Jakarta

3. Trihendradi C, 2009. 7 Langkah Mudah Melakukan Analisis Statistik 


\section{DynamicSainT}

Jilid. V No. 1., April 2020

Menggunakan SPSS 17. Penerbit ANDIYogyakarta

4. Tarore Huibert, Mandagi Robert J.M., 2006. Sistem Manajemen Proyek dan Konstruksi (SIMPROKON), Tim Penerbit JTS Fakultas Teknik Unsrat Manado.

5. Pudjosunarto Mulyadi Drs. 1991. Evaluasi Proyek.penerbit Liberti.Yogyakarta.

6. Suharto Imam, 1998. Menejemen Proyek dari Konseptual Sampai Operasional, Jilid 1. Jakarta. Erlangga.

7. Sugiono Dr, dan Wibowo Eri S.Pd, 2000. Statistik Non Parametris (AplikasiProgram SPSS), Alva Beta, Bandung.

8. Soeharto I, 1995. Manajemen Proyek dan Konseptual Sampai Operacional Earlangga, Jakarta.

9. Wahana Komputer, 2010. Mudah Belajar Statistik Dengan SPSS 18, Penerbit ANDY Yogyakarta \& Wahana Komputer Semarang.

10. Wahana Komputer, 2012. Solusi Praktis \& Mudah menguasai SPSS 20 Untuk Pengolahan Data, PenerbitWahana Komputer Semarang \&ANDY Yogyakarta. 